\title{
Deteksi dan Identifikasi Fitoplasma yang Berasosiasi dengan Penyakit Layu Kelapa Di Pulau Derawan, Kalimantan Timur
}

\section{Detection and Identification of Phytoplasmas Associated with Coconut Wilt Disease in Derawan Island, East Kalimantan}

\author{
Agus Eko Prasetyo ${ }^{1 *}$, Kikin Hamzah Mutaqin ${ }^{2}$, Giyanto ${ }^{2}$ \\ ${ }^{1}$ Pusat Penelitian Kelapa Sawit, Medan 21058 \\ ${ }^{2}$ Institut Pertanian Bogor, Bogor 16680
}

\begin{abstract}
ABSTRAK
Kelapa merupakan komoditas utama yang berperan sebagai penambah pendapatan petani di Pulau Derawan. Penelitian ini bertujuan mendeteksi dan mengidentifikasi fitoplasma yang berasosiasi dengan penyakitlayukelapadiPulauDerawan.Penyakitlayukelapaditunjukkandarigejaladaunmenguning,pelepah maupun daun kelapa terlihat memendek, daun tua mengering dan lunglai, serta buah menjadi gugur. Tanda penyakit fitoplasma diamati dari jaringan floem batang menggunakan mikroskop fluoresen dan elektron. Identifikasi fitoplasma dilakukan dengan metode nested-PCR dan perunutan DNA sikuen gen 16S rRNA. DNA fitoplasma berukuran $1.25 \mathrm{kpb}$ berhasil diamplifikasi secara molekuler dengan nested -PCR menggunakan pasangan primer P1/P7 yang dilanjutkan dengan pasangan primer R16F2n/R16R2. Analisis runutan DNA fitoplasma tersebut menunjukkan bahwa fitoplasma yang berasosiasi dengan penyakit layu kelapa di Pulau Derawan termasuk dalam kelompok 16SrII (witches broom phytoplasma) dan 16SrXI (ca. Phytoplasma oryzae).
\end{abstract}

Kata kunci: gen 16SrRNA, jaringan floem, nested -PCR, perunutan DNA

\begin{abstract}
Coconut is a major commodity in Derawan island as source of additional income for the farmers. Research was conducted to detect and identify phytoplasmas associated with coconut wilt disease in Derawan island. Coconut wilt disease was indicated by the typical symptoms, i.e. leaf yellowing, shorten of coconut sheaths and leaves, necrosis and collapse of old leaves, and also nut fall. The presence of phytoplasmas in phloem tissues of coconut stem was observed using fluorescence and electron microscope. Identification of phytoplasmas was carried out by nested-PCR and sequencing of the 16S rRNA gene. DNA fragment of phytoplasma with the size of $1.25 \mathrm{kbp}$ was successfully amplified using primer pairs P1/P7, followed by primer pairs R16F2n/R16R2. Sequence analysis of the amplified fragments showed that phytoplasma associated with coconut wilt disease in Derawan island belongs to 16SrII (witches broom phytoplasma) and 16SrXI (ca. Phytoplasma oryzae) groups.
\end{abstract}

Key words: DNA sequencing, 16SrRNA gene, nested PCR, phloem tissue

*Alamat penulis korespondensi: Pusat Penelitian Kelapa Sawit. Jalan Brigjend Katamso No. 51, Medan 21058 Tel: 0261-7862488,Surel: prasetyo_marihat@yahoo.com 


\section{PENDAHULUAN}

Kelapa (Cocos nucifera) merupakan komoditas sosial kedua setelah padi di Indonesia dengan luas areal sekitar 3.7 juta ha atau setara dengan $1 / 3$ luas penanaman kelapa dunia (Deptan 2007). Di Pulau Derawan, kelapa ditanam untuk penambah pendapatan masyarakat dan nilai eksotis pantai yang menjadi maskot pariwisata di provinsi Kalimantan Timur. Keberadaan tanaman kelapa ini mulai berkurang karena penyakit layu kelapa yang diduga disebabkan oleh fitoplasma.

Di Indonesia, penyakit serupa dikenal dengan penyakit layu Kalimantan yang menyerang tanaman kelapa di daerah Sampit (Kalimantan Tengah) yang disebabkan oleh ca. Phytoplasma oryzae (Warokka et al. 2006). Galur yang berbeda, yaitu ca. Phytoplasma cynodontis juga dilaporkan menyebabkan penyakit coconut lethal decline di Malaysia (Nejat et al. 2009). Galur fitoplasma yang diketahui menyebabkan kerugian sangat besar pada tanaman kelapa di daerah Amerika dan Afrika ialah ca. Phytoplasma palmae, penyebab penyakit lethal yellowing (Tymon et al. 1998; Harrison et al. 2002; Myrie et al. 2006) dan penyakit ini merupakan organisme penganggu tanaman karantina A1 di Indonesia. Oleh karena lethal yellowing dapat juga menyerang kelapa sawit di Indonesia maka adanya infeksi fitoplasma pada tanaman Palmae lainnya perlu segera diidentifikasi penyebabnya.

Deteksi dan identifikasi fitoplasma penyebab penyakit layu kelapa di Pulau Derawan penting dilakukan untuk mencegah terjadinya ledakan penyakit. Penelitian ini bertujuan mendeskripsikan gejala morfologi dan histopatologi penyakit layu kelapa di Pulau Derawan, mendeteksi keberadaan fitoplasma menggunakan teknik nested PCR (nPCR), dan mengidentifikasi serta mengklasifikasikan fitoplasma yang diperoleh berdasarkan sikuen gen 16S rRNA.

\section{BAHAN DAN METODE}

\section{Pengambilan Sampel Tanaman}

Sampel diambil berdasarkan pada pengamatan visual morfologi daun, pelepah, batang, buah, dan akar yang berbeda dari tanaman sehat. Sampel untuk pengamatan histopatologi tanaman sakit diambil menggunakan bor besi berlubang untuk mendapatkan potongan batang berbentuk seperti pensil berdiameter sekitar $0.5 \mathrm{~cm}$.

Sampel berupa serbuk batang untuk ekstraksi DNA diperoleh dengan cara mengebor batang pada ketinggian sekitar $1 \mathrm{~m}$ dari permukaan tanah sedalam 15-20 cm (Oropeza et al. 2002). Jenis tanaman yang dijadikan sampel menunjukkan gejala ringan (daun menguning dan mulai klorosis), berat (daun klorosis, mengering dan tidak memproduksi buah), dan tanaman yang tidak bergejala penyakit. Masing-masing gejala diambil dari 6 tanaman dengan 3 sisi pengeboran yang berbeda per tanaman, jadi ada 54 sampel. Sebagai kontrol digunakan sampel tanaman kelapa terserang penyakit layu Kalimantan dari daerah Sampit dan beberapa sampel tanaman kacang tanah dan kedelai yang terserang penyakit sapu dari Bogor.

\section{Pengamatan Histopatologi}

Studi histopatologi pada jaringan pengangkutan floem dilakukan dengan menggunakan mikroskop fluoresen dan elektron. Metode pewarnaan 4,6-diamino2-phenylindole (DAPI) digunakan pada pengamatan fitoplasma menggunakan mikroskop fluoresen (Schaad 2001). Sampel batang dipotong sepanjang $0.5 \mathrm{~cm}$ kemudian difiksasi dengan larutan glutaraldehida $(5 \%$ dalam bufer fosfat $0.1 \mathrm{M} \mathrm{pH} \mathrm{7)} \mathrm{dan} \mathrm{disimpan}$ di dalam lemari pendingin. Batang yang telah difiksasi dicuci dengan bufer fosfat $0.1 \mathrm{M}$, lalu dipotong dengan freezing microtome setebal $10 \mu \mathrm{m}$ dan diwarnai dengan cara meneteskan larutan DAPI (0.1 mg DAPI dalam $100 \mathrm{~mL}$ bufer fosfat) pada gelas preparat dan simpan selama 30 menit pada ruangan yang gelap. Pengamatan dilakukan segera atau kurang dari 48 jam.

Pengamatan dengan scanning electron microscopy (SEM) dilakukan dengan memotong sampel batang 3-5 mm, kemudian difiksasi dengan larutan glutaraldehida $6 \%$ serta $\mathrm{OsO}_{4} 2 \%$. Spesimen diwarnai menggunakan larutan uranil asetat $2 \%$, diinkubasi selama 2 hari pada suhu $37^{\circ} \mathrm{C}$, 
dan didehidrasi secara berseri dengan larutan etanol 10\% sampai etanol absolut. Spesimen batang diinfiltrasi dengan larutan $\mathrm{CO}_{2}$ sampai kering serta dilapisi dengan $5 \mathrm{~nm}$ karbon dan 20-25 nm emas di dalam mesin pengering berputar (Musetti dan Favali 2004).

\section{Ekstraksi DNA dari tanaman}

Metode ekstraksi DNA yang digunakan berdasarkan metode yang digunakan Zhang et al. (1998). Sebanyak $300 \mathrm{mg}$ serbuk batang digerus dalam nitrogen cair sampai menjadi bubuk halus. Bubuk gerusan dimasukkan ke dalam tabung eppendorf $1.5 \mathrm{~mL}$ dan ditambahi bufer CTAB $0.8 \mathrm{~mL}$ suhu $60{ }^{\circ} \mathrm{C}$. Suspensi sampel lalu diinkubasi pada suhu yang sama selama 20 menit (dicampur rata dengan membolak-balikkan tabung 3-4 kali secara perlahan), lalu didinginkan dalam es. Kemudian ke dalam suspensi ditambahkan kloroform:isoamilalkohol $(24: 1 \mathrm{v} / \mathrm{v})$ sebanyak $0.7 \mathrm{~mL}$, dicampur rata dengan vortex dan disentrifugasi dengan kecepatan $3000 \mathrm{~g}$ pada suhu $4{ }^{\circ} \mathrm{C}$ selama 10 menit. Supernatan yang terbentuk dipindahkan ke dalam tabung eppendorf baru dan ditambahkan kloroform:isoamilalkohol dengan volume yang sama dan disentrifugasi kembali. Supernatan yang didapatkan dipindahkan ke tabung eppendorf baru dan ditambahi isopropanol dingin sebanyak $0.6 \mathrm{~mL}$, kemudian DNA dipresipitasi dengan kecepatan $10000 \mathrm{~g}$ pada suhu $4{ }^{\circ} \mathrm{C}$ selama 7 menit. Supernatan yang terbentuk dibuang dan selanjutnya pelet DNA dicuci dengan ethanol $70 \%$ dingin sebanyak dua kali; setiap kali pencucian DNA dipresispitasi dengan cara sentrifugasi. Pelet DNA diresuspensi dalam $0.1 \mathrm{~mL}$ bufer TE dan disimpan di lemari pendingin pada suhu $-20{ }^{\circ} \mathrm{C}$ sampai siap digunakan.

\section{Amplifikasi DNA dengan metode nested PCR}

DNA hasil ekstraksi diamplifikasi menggunakan pasangan primer universal fitoplasma, P1 (5'-AAG AGT TTG ATC CTG GCT CAG GAT T-3') / P7 (5'-CGT CCT TCA TCG GCT CTT-3') (Deng dan Hiruki 1991). Produk PCR diamplifikasi menggunakan pasangan primer R16F2n (5'-GAAACG ACT GCTAAGACTGG-3')/R16R2 (5'-TGACGG GCG GTG TGT ACAAAC CCC G-3') (nested PCR) yang menempel pada bagian dalam sikuen DNA produk PCR pertama sehingga amplikon DNA yang didapatkan berukuran lebih pendek (Gundersen dan Lee 1996).

Reaksi PCR dilakukan dengan volume total $10 \mathrm{~mL}$ yang terdiri atas $1 \mathrm{~mL}$ template DNA, $1 \mathrm{~mL} 2 \mathrm{mM}$ dNTPs, $0.6 \mathrm{~mL} 25 \mathrm{mM}$ $\mathrm{MgSO}_{4}, 1 \mathrm{~mL}$ primer forward (2 pmol), $1 \mathrm{~mL}$ primer reverse ( $2 \mathrm{pmol}), 0.1 \mathrm{~mL}$ Taq KOD plus Neo (Toyobo, Jepang) dan $4.3 \mathrm{~mL} \mathrm{dH}_{2} \mathrm{O}$. Siklus PCR disajikan pada Tabel 1. Sebanyak $1 \mathrm{~mL}$ produk PCR pertama digunakan sebagai cetakan DNA untuk PCR kedua dengan pasangan primer R16F2n/R16R2. Program PCR yang digunakan sama seperti PCR pertama hanya berbeda pada suhu penempelan primer, yakni $57^{\circ} \mathrm{C}$.

\section{Perunutan DNA dan Analisisnya}

DNA hasil nested PCR (nPCR) dikirim First BASE (Malaysia) untuk perunutan DNA. Homologi sikuen DNA fitoplasma dari sampel kelapa dibandingkan dengan sikuen DNA yang terdeposit pada GenBank dianalisis menggunakan program basic local alighment search tool (BLAST) pada National Centre For Biotecnological Information (NCBI). Pohon filogenetika runutan sikuen 16S RNA dikonstruksi dengan piranti lunak PAUP 4.0 menggunakan nilai bootstrap 1000 kali.

\section{HASIL}

\section{Morfologi dan Histopatologi Penyakit Layu Kelapa}

Penyakit layu kelapa di Pulau Derawan ditandai oleh daun yang menguning, pelepah

Tabel 1 Siklus PCR dengan pasangan primer P1/P7

\begin{tabular}{lccc}
\hline Tahapan & $\begin{array}{c}\text { Suhu } \\
\left({ }^{\circ} \mathrm{C}\right)\end{array}$ & $\begin{array}{c}\text { Waktu } \\
(\text { detik })\end{array}$ & Siklus \\
\hline Denaturasi awal & 94 & 120 & 1 \\
Denaturasi & 94 & 15 & 35 \\
Penempelan primer & $54^{*}$ & 30 & \\
Ekstensi & 68 & 150 & \\
\hline *Nested PCR suhu penempelan primer $57^{\circ} \mathrm{C}$ &
\end{tabular}


maupun daun kelapa yang muncul terlihat lebih pendek daripada tanaman kelapa yang sehat, nekrosis daun dimulai dari bagian daun yang tua (bawah), pangkal pelepah tua lunglai, terjadinya penguguran buah kelapa yang masih muda atau jika masih ada buah kelapa yang tersisa sampai besar dan masak, biasanya hanya 1 atau 2 biji saja. Gejala akhir penyakit ini ialah mengeringnya seluruh pelepah dan daun kelapa, rontok dan terlihat hanya seperti tonggak batang kayu (Gambar 1).

Hasil pengamatan jaringan pengangkut batang dan akar dengan pewarnaan DAPI menunjukkan ada akumulasi fitoplasma pada jaringan floem. Bagian-bagian yang menyala fluoresensi pada jaringan floem batang tanaman bergejala diduga merupakan DNA fitoplasma (Gambar 2a), sedangkan pada jaringan tanaman sehat bagian fluoresensi tidak terlihat (Gambar 2b). Pengamatan

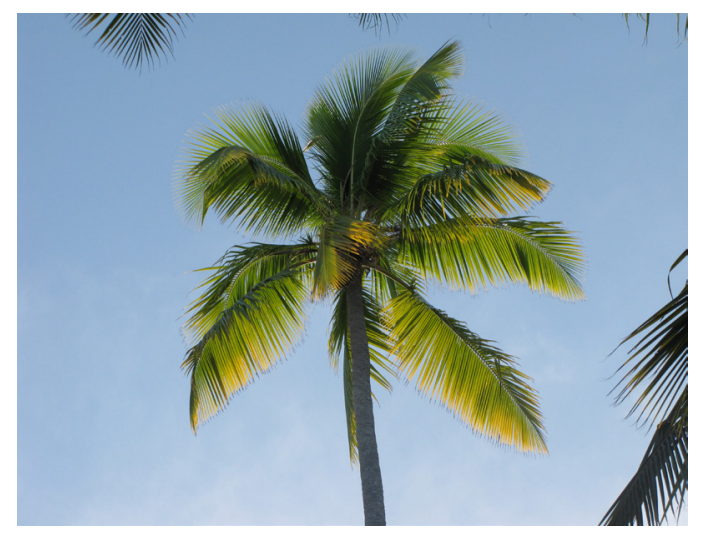

a jaringan dengan SEM menunjukkan sel-sel yang diduga fitoplasma tampak melekat pada dinding-dinding sel floem, walaupun tidak terlihat menggerombol (Gambar 2c). Bentuk sel fitoplasma pleomorfik dengan diameter berkisar antara $0.5 \mu \mathrm{m}$ dan $0.9 \mu \mathrm{m}$.

\section{Identifikasi dan Karakter Molekuler Fitoplasma}

Hasil amplifikasi DNA pada PCR yang pertama menunjukkan bahwa pasangan primer P1/P7 hanya mengamplifikasi kontrol positif DNAfitoplasma yang berasal dari kacang tanah dan kedelai (Gambar 3a, lajur 14-15); DNA fitoplasma kelapa tidak teramplifikasi. Setelah dilakukan nested PCR dengan pasangan primer R16F2n/R16R2, semua sampel dari tanaman kelapa bergejala layu ringan dan berat dari Pulau Derawan menunjukkan positif teramplifikasi, sedangkan pada tanaman yang

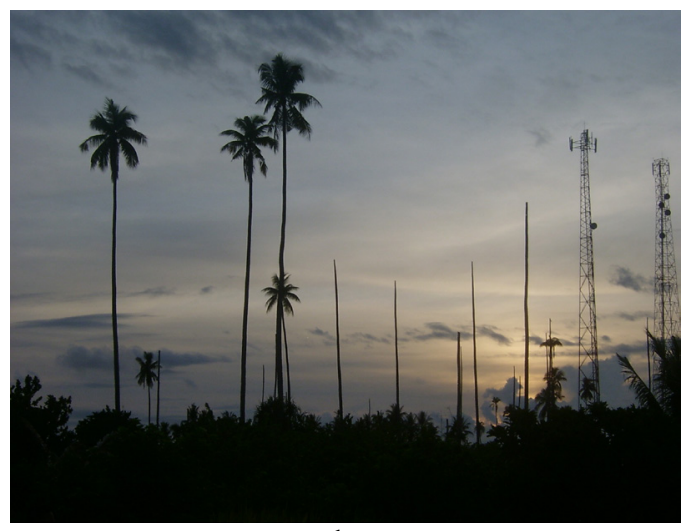

b

Gambar 1 Gejala penyakit layu kelapa di Pulau Derawan. a, Daun kelapa menguning; b, Gejala akhir penyakit yang tampak hanya batang tanpa daun.

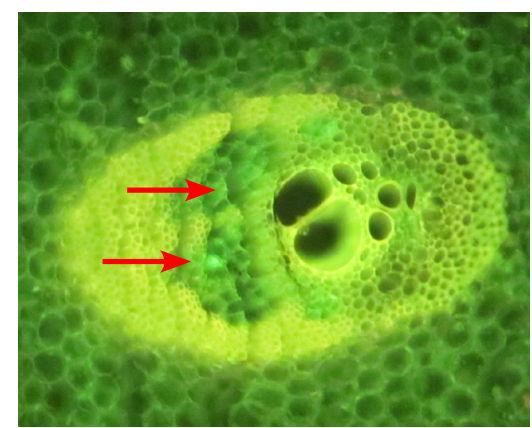

a

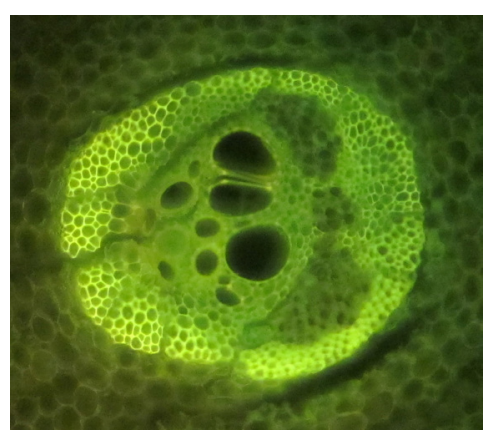

b

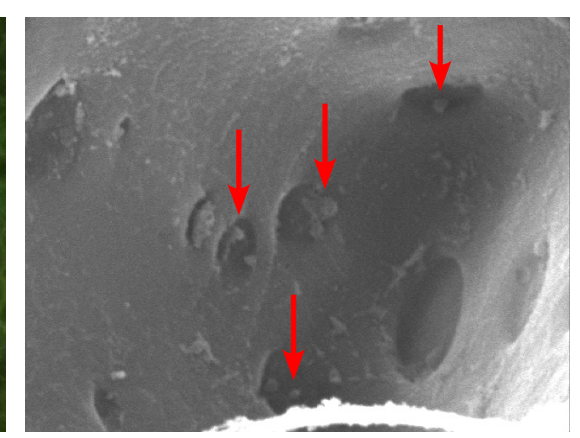

c

Gambar 2 Potongan melintang jaringan pengangkutan pada batang kelapa. a, Batang kelapa sakit dengan pewarnaan DAPI, bagian menyala fluoresen (panah) yang tampak pada floem diduga merupakan fitoplasma; b, Batang kelapa sehat dengan pewarnaan DAPI; dan c, Sel floem batang kelapa yang diduga mengandung fitoplasma (panah) yang terlihat menggunakan SEM. 
tidak bergejala hanya 3 tanaman yang positif (Gambar 3b).

Hasil analisis BLAST runutan DNA menunjukkan $77.78 \%$ dari 36 sampel (termasuk tanaman bergejala berat, ringan dan tidak bergejala) identik dengan DNA beberapa galur fitoplasma dan sisa $22.22 \%$ sampel lainnya teridentifikasi bukan merupakan fitoplasma. Sebanyak 6 sampel DNA fitoplasma asal kelapa Pulau Derawan berhasil terunut sikuen 16S RNA-nya berukuran 1247 pb. Dari 6 sampel DNA yang dirunut, 5 sampel (Derawan 1-5) menunjukkan homologi yang tinggi terhadap kelompok witches broom phytoplasma (grup 16SrII) dengan nilai homologi 99\% terhadap sikuen gen $16 \mathrm{~S}$ rRNA Echinacea witches'-broom phytoplasma galur EWB6 dari Australia (JF340080.1). Sedangkan satu sampel sikuen DNA (Derawan 6) memiliki homologi yang tinggi terhadap $c a$. Phytoplasma oryzae (grup 16SrXI) dengan nilai homologi $96 \%$ terhadap sikuen gen 16S rRNA 'Psammotettix cephalotes'flower stunt phytoplasma galur BVK (HQ589192) (Tabel 2). Hal ini menunjukkan penyebab layu kelapa di Pulau Derawan merupakan 2 kelompok fitoplasma yang berbeda.

Analisis filogenetika keenam sikuen 16S RNA fitoplasma kelapa asal Derawan terhadap berbagai galur fitoplasma yang digunakan Hodgets dan Dickinson (2010) menunjukkan bahwa lima sikuen DNA fitoplasma (Derawan 1-5) memiliki kekerabatan yang tinggi dengan kelompok witches broom phytoplasma (grup
16SrIIA-D) sikuen DNA Derawan 6 dan sikuen DNA kalimantan wilt dari Sampit mempunyai hubungan kekerabatan yang tinggi, tetapi relatif jauh dari witches broom phytoplasma dan ca. Phytoplasma oryzae (Gambar 4).

Pada penelitian ini, sikuen DNA yang mirip dengan spesies bukan fitoplasma meliputi Bacillus megaterium, Bacillus spp., Clostridium sp., Friedmaniella lacustris, dan Lagionella birminghamensis memiliki nilai homologi 93-96\%, dan termasuk ke dalam bakteri Gram positif (Tabel 2).

\section{PEMBAHASAN}

Menurut Leon et al. (1996), pada stadia perkembangan penyakit lethal yellowing awal pada tanaman kelapa, konduktansi stomata menurun pada kedua sisi atas daun, tengah dan pangkal pelepah. Perilaku stomata ini memengaruhi pertukaran gas, fotosintesis, dan transportasi air. Akibatnya daun kelapa menguning dengan penurunan laju fotosintesis, kandungan protein, klorofil, dan karotenoid. Aguilar et al. (2009) meneliti terjadinya penurunan kandungan sitokinin yang drastis pada daun yang bergejala penyakit lethal yellowing yang mengakibatkan perilaku stomata cenderung menutup. Leon et al. (1996) juga berpendapat bahwa tanaman kelapa yang sakit akan menghasilkan asam absisat dan etilena yang sangat tinggi yang berakibat terjadi ketidakseimbangan hormon. Hormon-hormon ini akan memacu penuaan

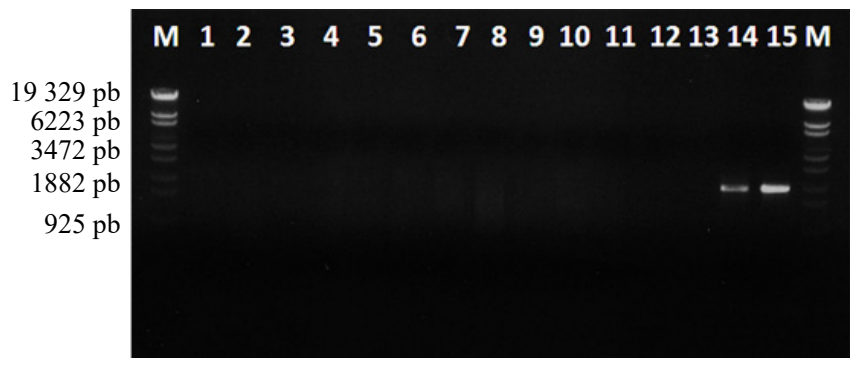

a

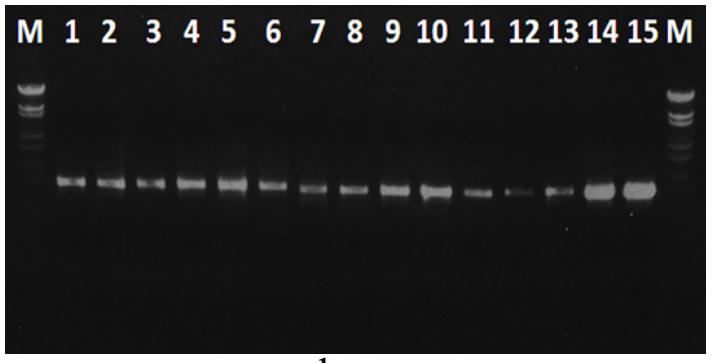

$\mathrm{b}$

Gambar 3 Amplifikasi sampel yang diduga terinfeksi fitoplasma menggunakan dua primer. a, Primer P1/P7; dan b, Primer R16F2n/R16R2. M, penanda DNA $\lambda$ Eco T14I digest; 1-2, Sampel kelapa tidak bergejala dari Pulau Derawan; 3-6, Sampel kelapa bergejala ringan dari Pulau Derawan; 7-10, Sampel kelapa bergejala berat dari Pulau Derawan; 11-13, Sampel kelapa bergejala dari Sampit; 14, Sampel kedelai; 15, Sampel kacang tanah. 


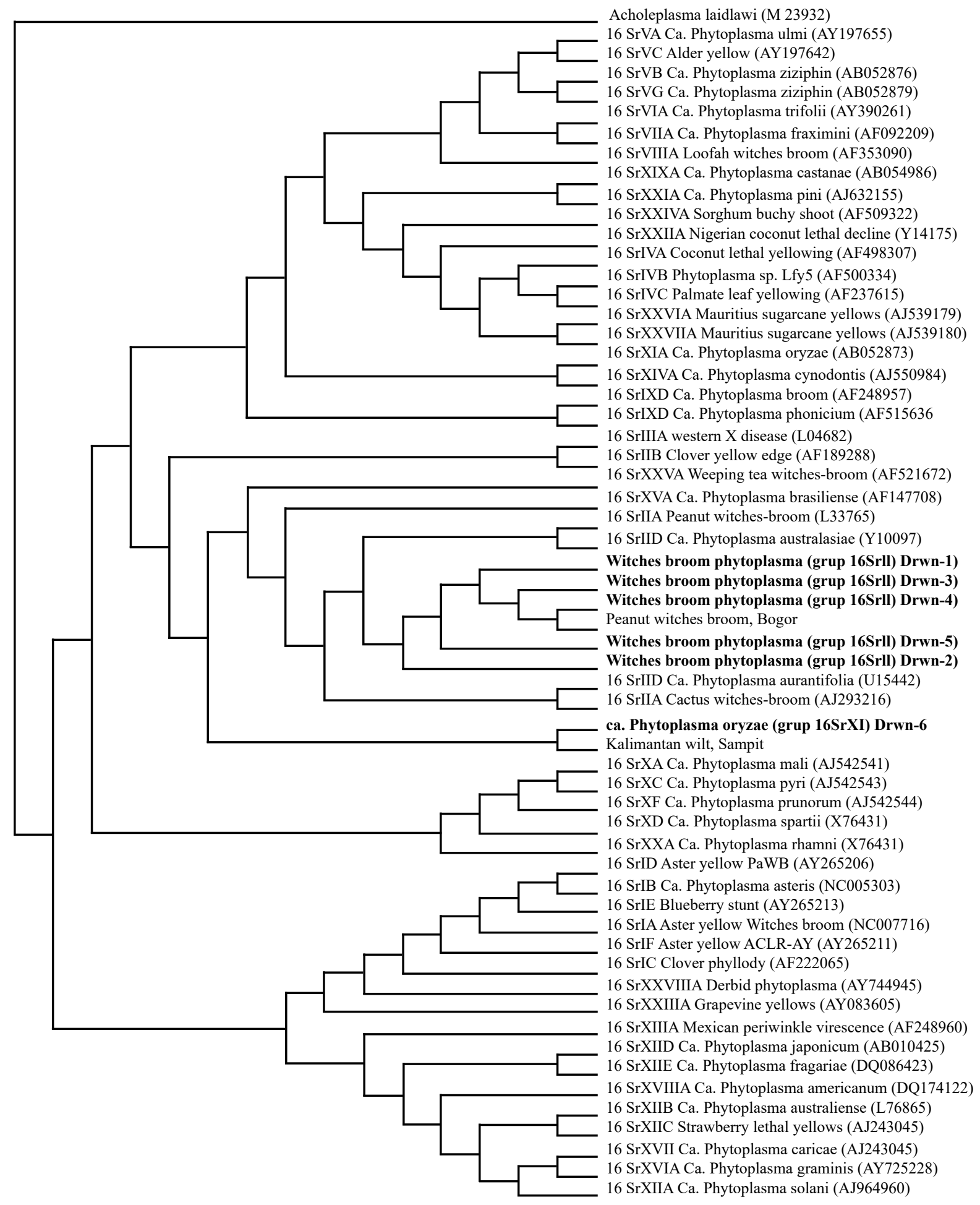

Gambar 4 Pohon filogenetika fitoplasma sampel dari kelapa di Pulau Derawan terhadap galur fitoplasma dari setiap grup berdasarkan 16S rRNA (Hodgets dan Dickinson 2010) yang tersimpan di GenBank menggunakan program PAUP 4.0 dengan nilai bootstrap 1000 kali.

daun dan mengakibatkan pelepah lunglai serta gugurnya buah yang masih muda (Musetti 2010).

Pewarnaan DAPI dan pengamatan SEM merupakan metode deteksi fitoplasma yang relatif mudah dan cepat, meskipun kurang kuat untuk membedakan antara sel mikroorganisme lain atau komponen sel tumbuhan dari sel fitoplasma (Schaad 2001; Franova et al. 2007). Oleh karena itu, teknik ini hanya digunakan sebagai deteksi awal keberadaan patogen (Arismendi et al. 2009). 
Tabel 2 Hasil analisis BLAST 16S RNA fitoplasma dari Pulau Derawan terhadap DNA fitoplasma pada GenBank asal tanaman kelapa, kacang tanah, dan kedelai

\begin{tabular}{ccllc}
\hline $\begin{array}{c}\text { s sikuen } \\
\text { yang sama }\end{array}$ & $\begin{array}{c}\text { Ukuran } \\
(\mathrm{pb})\end{array}$ & \multicolumn{1}{c}{ Asal contoh } & $\begin{array}{c}\text { Subspesies yang mirip dari uji BLAST } \\
\text { (no aksesi) }\end{array}$ & $\begin{array}{c}\text { Kemiripan } \\
(\%)\end{array}$ \\
\hline 2 & 1247 & Kelapa Pulau Derawan & WB Phytoplasma (JN885462.1) & 99 \\
5 & 1247 & Kelapa Pulau Derawan & WB Phytoplasma (JN885462.1) & 99 \\
7 & 1247 & Kelapa Pulau Derawan & WB Phytoplasma (JN885462.1) & 99 \\
3 & 1247 & Kelapa Pulau Derawan & WB Phytoplasma (JN885462.1) & 99 \\
4 & 1247 & Kelapa Pulau Derawan & WB Phytoplasma (JN885462.1) & 99 \\
2 & 1247 & Kelapa Pulau Derawan & Ca. P. oryzae (D12581.2) & 95 \\
1 & 1246 & Kelapa Sampit & Ca. P. oryzae (D12581.2) & 95 \\
2 & 1247 & Kacang tanah Bogor & WB Phytoplasma (JN885462.1) & 99 \\
2 & 1247 & Kedelai Bogor & WB Phytoplasma (JN885462.1) & 99 \\
1 & 1292 & Kelapa Pulau Derawan & B. megaterium (HQ336301.1) & 96 \\
1 & 1292 & Kelapa Pulau Derawan & B. megaterium (CP003017.1) & 95 \\
1 & 1292 & Kelapa Sampit & B. megaterium (GU125638.1) & 94 \\
1 & 1228 & Kelapa Pulau Derawan & Clostridium sp. (AB550230.1) & 93 \\
1 & 1256 & Kelapa Sampit & Clostridium sp. (DQ978215.1) & 94 \\
1 & 1298 & Kelapa Pulau Derawan & Bacillus spp. (JN800333.1) & 94 \\
1 & 1233 & Kelapa Pulau Derawan & F. lacustris (NR_028884.1) & 96 \\
1 & 1252 & Kelapa Sampit & L. birminghamensis (NR_044953.1) & 95 \\
\hline
\end{tabular}

$\overline{\mathrm{WB}}$, witches broom

Deteksi lanjutan yang lebih baik ialah secara molekuler menggunakan metode PCR.

PCR dengan primer P1/P7 merupakan teknik identifikasi fitoplasma paling umum yang menghasilkan sikuen DNA berukuran sekitar $1.8 \mathrm{~kb}$ yang di dalamnya terkandung gen yang dekat dengan awal 16S rRNA, daerah interspacer (ITS), dan bagian ujung 5' gen 23S rRNA. Deteksi lanjut dengan nPCR dari hasil amplikon PCR pertama yang memperlihatkan adanya fragmen DNA dari sampel kelapa yang berukuran sekitar $1.25 \mathrm{~kb}$ yang mengandung internal gen 16S rRNA (Gundersen dan Lee 1996). Nested PCR diperlukan untuk memperpendek ukuran produk PCR sehingga fitoplasma lebih mudah diidentifikasi sesuai dasar klasifikasi fitoplasma berdasarkan gen 16S rRNA (Hodgets dan Dickinson 2010). Hasil penelitian ini menunjukkan juga bahwa tanaman kelapa yang tidak menunjukkan gejala/ belum bergejala terdeteksi positif terinfeksi fitoplasma dengan nPCR. Hal ini membuktikan bahwa metode nPCR dapat digunakan untuk mendeteksi fitoplasma pada tanaman bergejala maupun tanaman yang tidak bergejala.

Fitoplasma erat berhubungan dengan bakteri Gram positif khususnya grup Bacillus dan Clostridium yang menjadi nenek moyang fitoplasma (Bai et al. 2006). Hal ini berarti banyak sikuen gen fitoplasma dan bakteri Gram positif yang akan memiliki kesamaan. Terdeteksinya berbagai galur bakteri Gram positif ini juga mengindikasikan bahwa primer fitoplasma yang digunakan belum spesifik mendeteksi fitoplasma sehingga hasil deteksi nPCR memerlukan konfirmasi melalui perunutan DNA.

Hasil identifikasi molekuler menunjukkan bahwa 6 sikuen DNA yang dirunut asal tanaman bergejala layu di Pulau Derawan disebabkan oleh 2 kelompok fitoplasma yang berbeda, yaitu 5 sampel DNA dari kelompok witches broom phytoplasma (grup 16SrII) dan satu sampel DNA memiliki homologi yang tinggi dengan ca. Phytoplasma oryzae (grup 16SrXI).

\section{DAFTAR PUSTAKA}

Aguilar MI, Espadas F, Maust B, Saenz L. 2009. Endogenous cytokinin content in coconut palms affected by lethal yellowing. J Plant Pathol. 91(1):141-146.

Arismendi NS, Andrade NS, Riegel RS, Carrilo RL. 2010. Presence of a phytoplasma 
associated with witches' broom disease in Ugni molinae Turcz. and Gaultheria phillyreifolia (Pers.) Slemuer determined by DAPI, PCR and DNA sequencing. Chilean J Agric Res. 70(1):26-33. DOI: https://doi.org/10.4067/S071858392010000100003.

Bai XD, Zhang JH, Ewing A, Miller SA, Radek AJ, Shevchenko DV, Tsukerman K, Walunas T, Lapidus A, Campbell JW, Hogenhout SA. 2006. Living with genome instability, the adaptation of phytoplasmas to diverse environments of their insect and plant hosts. J Bacteriol. 188:36823696. DOI: https://doi.org/10.1128/ JB.188.10.3682-3696.2006.

Deng S, Hiruki C. 1991. Amplification of 16S rRNA genes from culturable and non culturable mollicutes. J Microbiol Methods. 14:53-61. DOI: https://doi. org/10.1016/0167-7012(91)90007-D.

[Deptan] Departemen Pertanian. 2007. Prospek dan Arah Pengembangan Agribisnis Kelapa. Ed ke-2. Jakarta (ID): Departemen Pertanian.

Franova J, Petrzik K, Paprstein F, Kucerova J, Navratil M, Valova P. 2007. Experiences with phytoplasma detection and identification by different methods. Bull Insectol. 60:247-248.

Gundersen DE, Lee IM. 1996. Ultrasensitive detection of phytoplasmas by nested PCR assays using two universal primer pairs. Phytopathol Mediterrania. 35:144-151.

Harrison NA, Myrie W, Jones P, Carpio ML, Castilo M, Doyle MM, Oropeza C. 2002. 16S rRNA interoperon sequence heterogeneity distinguishes strain populations of palm lethal yellowing phytoplasma in the Carribean region. Ann Appl Biol. 141:183-193. DOI: 1https://doi. org/10.1111/j.1744-7348.2002.tb00211.x.

Hodgets J, Dickinson M. 2010. Phytoplasma phylogeny and detection based on genes other than 16S rRNA. Di dalam: Weintraub PG, Jones P, editor. Phytoplasmas: Genomes, Plant Hosts and Vectors. Wallingford (UK): CAB International. hlm 108-128.
Leon R, Santamaria JM, Alpizar L, Escamilla JA, Oropeza C. 1996. Physiological and biochemical changes in shoots of coconut palms affected by lethal yellowing. New Phytologist. 134:227-234. DOI: https:// doi.org/10.1111/j.1469-8137.1996. tb04627.x.

Musetti R, Favali MA. 2004. Microscopy techniques applied to study of phytoplasma diseases: traditional and innovative methods. Di dalam: Mendez-Vilas A, Labajos-Broncano L, editor. Current Issues on Multidiciplinary Microscopy Research and Education. hlm 72-80.

Musetti R. 2010. Biochemical changes in plant infected by phytoplasma. Di dalam: Weintraub PG, Jones P, editor. Phytoplasmas: Genomes, Plant Hosts and Vectors. Wallingford (UK): CAB International. hlm 132-146.

Myrie WA, Paulraj L, Dollet M, Wray D, Been BO. 2006. First report of lethal yellowing disease of coconut palms caused by phytoplasma on Nevis Island. Plant Dis. 90(6):834. DOI: https://doi.org/10.1094/ PD-90-0834A.

Nejat N, Sijam K, Abdullah SNA, Vadamalai G, Dickinson M. 2009. Molecular characterization of a phytoplasma associated with coconut yellow decline (CYD) in Malaysia. Am J Appl Sci. 6(7):1331-1340. DOI: https://doi. org/10.3844/ajassp.2009.1331.1340.

Oropeza C, Cordova I, Narvaez M, Harrison N. 2002. Palm Trunk Sampling for DNA Extraction and Phytoplasma Detection. Florida (US): University of Florida.

Schaad NW. 2001. Initial identification of common genera. Di dalam: Schaad NW, Jones JB, Chun W, editor. Laboratory Guide for Identification of Plant Pathogenic Bacteria. Edisi ke-3. St. Paul (US): APS Pr. hlm 1-6.

Tymon AM, Jones P, Harrison NA. 1998. Phylogenetic relationships of coconut phytoplasmas and the development of specific oligonucleotide PCR primers. Ann Appl Biol. 132:437-452. DOI: https://doi. org/10.1111/j.1744-7348.1998.tb05220.x. 
Warokka JS, Jones P, Dickson MJ. 2006. Zhang YP, Uyemoto JK, Kirkpatrick BC. Detection of phytoplasma associated with kalimantan wilt disease of coconut by the polymerase chain reaction. J Littri. 12(4):154-160.

Weintraub PG, Wilson MR. 2010. Control of phytoplasma disease and vectors. Di 1998. A small-scale procedure for extracting nucleic acids from woody plants infected with various phytopathogens for PCR assay. J Virol Methods. 71:45-50. DOI: https://doi.org/10.1016/S0166dalam: Weintraub PG, Jones P, editor. 0934(97)00190-0. Phytoplasmas: Genomes, Plant Hosts and Vectors. Wallingford (UK): CAB International. hlm 233-266. 